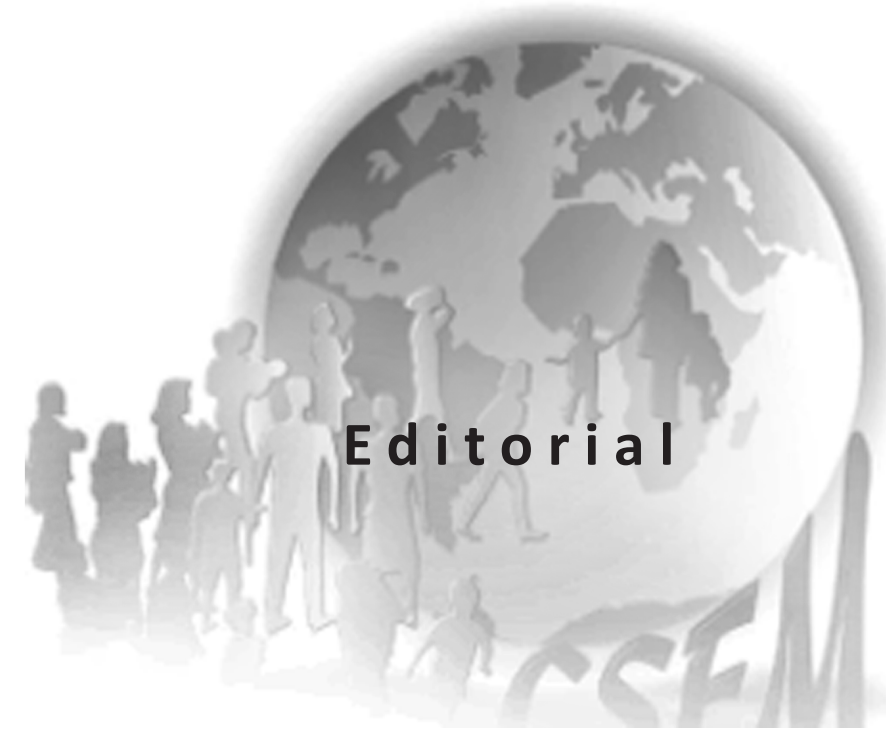

\title{
Criminalização das migrações e dos migrantes
}

O crescente aumento de fluxos migratórios mistos em nível internacional tem colocado a questão migratória no centro da pauta política em muitos países do mundo. Em um contexto global caracterizado por uma difundida crise econômico-financeira, a chegada de imigrantes e solicitantes de refúgio desperta, não raramente, sentimentos e atitudes de solidariedade e acolhida, mas também reações alarmistas, xenófobas e racistas. A globalização da violência bélica, que atinge também os países ocidentais, alimenta ainda mais um generalizado clima de suspeita em relação a qualquer imigrante, inclusive entre aqueles que fogem de guerras, de redes de tráfico de pessoas e de violações generalizadas de direitos humanos.

Com a expressão "criminalização das migrações" - tema do Dossiê da Revista REMHU n. 45 - entendemos o processo de transformação da fuga de milhões de migrantes e refugiados em bode expiatório, com o objetivo de encobrir as reais causas das crises sociais, políticas, econômicas e bélicas que assolam numerosos países e, ao mesmo tempo, de legitimar a implementação de um permanente "estado de exceção" - como diria Giorgio Agamben - a fim de combater os supostos "inimigos" do Estado-nação. A construção de muros, valas e outras barreiras físicas ou simbólicas - a "obsessão por fronteiras", nas palavras de Michel Foucher - visa, antes que dificultar o ingresso irregular de estrangeiros, garantir sua criminalização, sua deportabilidade (Nicholas De Genova), sua inclusão subordinada no território nacional. 
Nas palavras de Salvatore Palidda, a criminalização das migrações e dos migrantes é o fundamento de uma "tanatopolítica", que lucra - em termos econômicos, políticos e sociais - pela negação sistemática dos direitos fundamentais dos povos em fuga. Mas não é só isso. Trata-se de uma política securitária que viola os direitos também das populações autóctones, como demonstra, de forma brilhante, Didier Bigo, que analisa as "políticas paranoicas" das "listas de alertas" enquanto políticas que constroem "objetos del miedo [...] a fin de proporcionar justificación para una serie de medidas que, de otro modo, serían rechazadas" (p. 15).

Tais políticas paranoicas, na realidade, não constituem uma novidade, tanto de um ponto de vista diacrônico quanto sincrônico. Marcia Anita Sprandel e Eduardo Domenech abordam, respectivamente, o iter de elaboração do Estatuto do Estrangeiro de 1980, no Brasil, e os processos legislativos de criminalização e de expulsão de imigrantes anarquistas na Argentina no começo do século $\mathrm{XX}$. Em ambos os casos, as leis migratórias foram utilizadas com o objetivo de atingir determinadas categorias de imigrantes: os considerados "indesejáveis" e supostamente prejudiciais para a assim chamada "segurança nacional".

Algo análogo ocorre, na atualidade, em vários contextos geográficos. Na América do Norte, as numerosas tentativas legislativas - mais ou menos bem-sucedidas - de criminalizar a entrada irregular de migrantes provocaram o aumento das violações de direitos humanos fundamentais, além de desencadear numerosas reações por parte dos migrantes. Nesse sentido, Nicholas De Genova analisa de forma aprofundada os slogans das manifestações de protesto do dia 1 o de maio de 2006 nos EUA, refletindo sobre o surgimento de uma política de imigração "queer" e antiassimilacionista. Já, Guillermo Yrizar Barbosa e Rafael Alarcón abordam as consequências das políticas de criminalização e de deportação no que diz respeito a núcleos familiares mexicanos com status migratório misto.

Salvatore Palidda, Natalia Debandi e Maria João Guia/João Pedroso trazem o contexto da União Europeia, com foco prioritário, respectivamente, na Itália, na França e em Portugal. Os autores abordam vários temas, como a exploração dos imigrantes por parte de autóctones (le nuove schiavitù, nas palavras de Palidda), a presença de estrangeiros nas cadeias, os preconceitos mediáticos sobre a incidência da criminalidade dos imigrantes, a difusão do assim chamado "delitto di faciès" (aspecto ou caráter somático ou de dicção), a utilização da deportação como política penal e migratória, e a difusão da "crimigração", ou seja, a "aplicação simultânea da lei penal a migrantes (que não cometeram crimes) e a aplicação da lei de imigração a condenados por crimes" (p. 132).

Essas reflexões atestam a profunda complexidade da relação entre criminalidade, migração e direito. Embora sofram numerosas violações de 
direitos humanos, tanto nos países de origem como naqueles de trânsito e de chegada, muitos migrantes e solicitantes de refúgio, com frequência, acabam sendo perseguidos por dispositivos legislativos que visam, antes que o respeito da dignidade do ser humano, o controle do excedente social.

É nessa ótica que Lila García analisa a política migratória na Argentina através do poder judicial, evidenciando a intersecção entre política criminal e política migratória e enfatizando várias incongruências na aplicação da lei; Guilherme Mansur Dias, por sua vez, desenvolve um estudo acerca do processo de negociação dos Protocolos Adicionais contra o Tráfico de Pessoas e o Contrabando de Migrantes, destacando a aproximação progressiva da temática migratória com a justiça criminal; finalmente, Aryadne Bittencourt Waldely, Fabrício Toledo de Souza, Matteo Louis Raul Meirelles Theubet, Natalia Cintra de Oliveira Tavares e Raísa Barcellos Nepomuceno, numa abordagem foucaultiana, ressaltam como as práticas de securitização e repressão estão espalhadas em um conjunto de dispositivos institucionais, práticas e discursos que visam docilizar os corpos dos migrantes.

O Dossiê da REMHU 45, em suma, visa alimentar a reflexão sobre a utilização ideológica de discursos, práticas e aparatos securitários, repressivos e criminalizantes com vistas a implementar políticas de contenção da migração, seleção dos fluxos e administração do excedente social. Esses dispositivos não provocam apenas a violação de direitos fundamentais de seres humanos em fuga, mas alimentam uma cultura xenófoba e racista que colide profundamente com a identidade da modernidade ocidental enquanto fundamentada na lógica da dignidade inalienável de cada ser humano.

Na seção Artigos da REMHU n. 45, Alberto Augusto Eichman Jakob aborda a migração na Amazônia brasileira, focando os migrantes transfronteiriços, os migrantes brasileiros e o papel desenvolvido pelas cidades de fronteira, a partir dos dados do Censo Demográfico de 2010 e da Contagem Populacional de 2007; em seguida, Marden Barbosa de Campos, ao discutir sobre o tema dos deslocamentos populacionais forçados e involuntários, sublinha como raramente as migrações, de fato, se enquadram nesses extremos e destaca o papel desenvolvido pela idade e pelo sexo no comportamento migratório; por fim, Yolanda GonzálezRábago analisa a emigração colombiana e as iniciativas de atores institucionais a fim de promover um maior engajamento dos migrantes com seu país de origem e a criação de uma cidadania transnacional.

O sociólogo angolano Paulo Inglês, na seção Relatos e Reflexões, apresenta notas de trabalho de campo de uma pesquisa que está sendo realizada no Uíge (Angola), junto a mulheres retornadas, no que diz respeito a programas de crédito, relações de confiança e gênero. 
A seção Resenhas, Teses e Dissertações encerra o número da Revista com uma resenha de Elizabeth Ruano.

Desejamos a todas e todos uma boa leitura.

Roberto Marinucci (Editor chefe da REMHU)

ISSN impresso: 1980-8585

ISSN eletrônico: 2237-9843

http://dx.doi.org/10.1590/1980-85852503880004501 